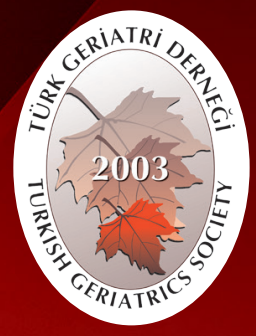

Turkish Journal of Geriatrics

DOI: 10.31086/tjgeri.2019150577

2019:22 (1):83-90

- Ömer SALT ${ }^{1}$ iD

- Mustafa Burak SAYHAN ${ }^{1}$ (D)

- Nejmi KÜÇÜKYAĞCl ${ }^{1}$ (D)

CORRESPONDANCE

Ömer SALT

Trakya University Faculty of Medicine, Emergency Medicine, Edirne, Turkey

Phone: 02842234210

e-mail: dromersalt@gmail.com

Received: 25/09/2018

Accepted: 18/12/2018

Trakya University Faculty of Medicine, Emergency Medicine, Edirne, Turkey
RESEARCH

\section{OCCUPATIONAL INJURIES AMONG THE ELDERLY ADMITTED TO THE EMERGENCY DEPARTMENT}

\section{Abstract}

Introduction: Occupational injuries are among the leading causes of morbidity and mortality worldwide. The rate of occupational injuries in the elderly is increasing daily and is directly proportional to the increase in the elderly population. This study aimed to examine occupational injuries in elderly patients (age, $>65$ years) admitted to the emergency department.

Materials and Method: This cross-sectional study included 122 patients aged $>65$ yearold who were admitted to the third level emergency department with an occupational injury between January 2016 and January 2018. The demographic characteristics of the patients, type of work accident, type of injury, injured body parts, and comorbid conditions were recorded and statistically evaluated.

Results: The mean patient age was $67.8 \pm 2.3$ years (mean $\pm S D) ; 85.5 \%(n: 108)$ of the patients were men, and $85.2 \%$ ( $n: 104)$ were retired. Hypertension was the most commonly observed comorbidity $(35.2 \%, \mathrm{n}: 43)$. Falls from the same or a high level were the most commonly observed injury mechanisms $(56.7 \%, \mathrm{n}: 74)$. The extremities were the most commonly injured body part (54.9\%, n:67); sprains/strains were the most commonly observed injury type $(47.5 \%$, $\mathrm{n}: 58)$. None of the injuries resulted in death.

Conclusion: The proportion of elderly workers is increasing owing to the rising elderly population worldwide. Because of increased cognitive and motor disabilities, there is an increased risk of occupational injuries in this age group. Thus, occupational injuries in the elderly should be more carefully evaluated in the emergency department.

Keywords: Aged; Emergency medicine; Occupational injury

\section{ACIL SERVISE BAŞVURAN YAŞLI HASTALAR ARASINDA İ̧̧ KAZALARI}

\section{$\ddot{\mathrm{O}}_{z}$}

Giriş: Iş kazaları dünya çapında morbidite ve mortalitenin önde gelen nedenleri arasındadır. Yaşlı popülasyonda görülen iş kazaları yaşı nüfusun artışına paralel olarak gün geçtikçe artmaktadır. Bu çalışmada acil servise başvuran 65 yaş üstü iş kazalarının incelenmesi amaçlanmıştır.

Gereç ve Yöntem: Kesitsel tipte planlanan bu çalışmaya Ocak 2016-Ocak 2018 tarihleri arasında üçüncü seviye acil servise başvuran 65 yaş üstü iş kazası vakaları dahil edilmiştir. Toplam 122 hastanın demografik özellikleri, iş kazası türü, yaralanma şekilleri, yaralanan vücut bölgeleri ve komorbid durumları kayıt altına alını istatistiksel değerlendirmeye tabi tutuldu.

Bulgular: Hastaların ortalama yaşı 67.8 \pm 2.3 (ort. \pm ss), \%85'i $(n=108)$ erkek ve \%85.2'si $(\mathrm{n}=104)$ emekli idi. En sık komorbid hastalık hipertansiyon $(\% 35.2, n: 43)$, en sık yaralanma mekanizması ise aynı seviyeden ya da yüksekten düşme $(\% 56.7, n=74)$ idi. Hastalarda en sık ekstremite yaralanması (\%54.9, n=67) tespit edilirken, en sık yaralanma türü ise burkulma/ gerilme tarzı $(\% 47.5, n=58)$ yaralanmalar idi. Hiçbir vaka mortal seyretmedi.

Sonuç: Dünya'da yaşlı nüfus oranındaki artışa paralel olarak yaşlı çalışan nüfus oranı da artmaktadır. Yaşııı̆ın doğası gereği kognitif ve motor fonksiyonlarda yaşanan gerilemeler bu yaş grubunda iş kazası görülme ihtimalini daha da artırmaktadır. Yaşı iş kazası hastalarının acil servis başvurularında çok daha dikkatli değerlendirme yapılmalıdır.

Anahtar sözcükler: Yaşlı; Acil tıp; İ̧ kazası 


\section{INTRODUCTION}

Occupational injuries are globally significant owing to the associated high mortality and morbidity as well as the loss of labor force and economy. Approximately 100 million cases of occupational injuries are annually reported worldwide (1). Although the risk of occupational injuries is determined by many factors, The employee's age is one of the most influential factors determining the risk of occupational injuries. Cognitive functions and motor skills decrease with age, resulting in an increased risk of occupational injuries $(2,3)$. Pransky et al. (4) reported that workers aged $>55$ years suffered more serious occupational injuries than those aged $<55$ years. Furthermore, smoking, alcohol abuse, and regular medications also impact the risk of developing occupational injuries.

The proportion of actively working elderly individuals is increasing in concert with the increased life expectancy. The Organization for Economic Cooperation and Development (OECD) reported that by $2025,33 \%$ of the male population and $38 \%$ of the females population working in Europe will be $\geq 60$ years of age (5). According to the Turkish Statistical Institute data, there were approximately 5,891,694 elderly individuals (age, $\geq 65$ years) in 2013 , which has increased by $17 \%$ over the past five years to reach a population of approximately 6,895,385 in 2017 (6). During this period, the elderly population comprised $7.7 \%$ of the total population in 2013 , which increased to $8.5 \%$ in 2017 . Men comprised $44 \%$ of the elderly population. According to population projections, the elderly population is predicted to comprise $10.2 \%$ of the total population in $2023,12.9 \%$ in 2030 , $16.3 \%$ in $2040,22.6 \%$ in 2060, in 2080 (6).

Although we lack sufficient data on our country, it is well known that the proportion of actively working elderly individuals has increased over the years. Economic difficulties are the primary reason why the elderly population continues to work even after retirement; further, because of insufficient pension salaries many elderly individuals continue to work even post retirement (7). Continuing to work at an old age causes some potential problems (8).
The musculoskeletal labor force capacity reportedly decreases by $25 \%$ between 30 and 65 years of age $(9,10)$. Hence, the risk of occupational injuries naturally increases if individuals continue to do the same work over 65 years of age. This increased risk has been reported for both machine-mounted jobs and for drivers aged $>65$ years $(8,11)$. Moreover, an increased risk of accidents has been reported for the elderly working in industries and as truck drivers. Age-related declines in motor skills and increased vision-related problems further increase the risk of accidents in the elderly (11). A study reported that workers aged 30-65 years had a 25\% reduction in musculoskeletal capacity, which reduced more rapidly after 65 years of age (9). Considering all these factors, the increased proportion of the elderly population and workers makes occupational injuries worth investigating in this age group.

\section{MATERIALS AND METHOD}

Ethical committee approval was obtained prior to study initiation. This study retrospectively analyzed elderly patients (age, >65 years) with occupational injuries who were admitted to the third level emergency department between January 2016 and January 2018. The hospital information registry system and emergency service records were scanned, and cases of occupational accidents in patients aged $>65$ years were detected. The scan detected total 128 cases; six cases were excluded because their patient records were not completely accessible. Data, such as age, sex, educational status, workplace, comorbidities, retirement status, accident type, and injury severity, were recorded in the study form. The data were analyzed using SPSS (Statistical Package for Social Sciences) version 22 (license number: 10240642). Here, descriptive statistics have been presented as numbers and percentages for qualitative data, and median, minimum, and maximum values have been presented for quantitative data. The ShapiroWilk test was used to assess the normality of the quantitative variables. The Mann-Whitney U-test was used to compare two independent groups, 
and the Kruskal-Wallis test was used to compare three independent groups when the data were not normally distributed. Pearson's Chi-square test was used to compare groups with two subjects, and Fischer's exact test was used when the minimum expected value was $<5$. Pearson's Chi-square test was used to compare ${ }^{3} 3$ groups, and Fischer's exact test was used as the final test when the smallest expected value was $>20 \%$.

If there were significant differences in three or more group comparisons, the group or groups that differed were identified using the Bonferroni's Multiple Comparison test. Spearman's correlation test was used to determine the relationship levels of the quantitative data that were not normally distributed. $p<0.05$ was considered statistically significant.

\section{RESULTS}

Total 108 (85.5\%) patients were men. The mean patient age was 67.8 \pm 2.3 (min-max, 65-77) years. Evaluation of the patients in terms of educational status revealed that 14 (11.5\%) were illiterate, 78 (64\%) were primaryschool graduates, $27(22.1 \%)$ were high school graduates, and 5 (3.4\%) were university graduates. The demographic characteristics of the patients are presented in Table 1.

Table 1. Demographic characteristics of the patients.

\begin{tabular}{|c|c|c|}
\hline Characterictic & $\begin{array}{l}\text { Mean } \pm S D \\
\text { (Min-max) }\end{array}$ & $\mathbf{p}$ \\
\hline Age & $\begin{array}{r}67.8 \pm 2.3 \\
(65-77) \\
\end{array}$ & \\
\hline Gender & n (\%) & \\
\hline Men & $108(85.5)$ & $<0.01$ \\
\hline Women & $14(14.5)$ & \\
\hline \multicolumn{3}{|l|}{ Marital status } \\
\hline Single & $11(9)$ & \\
\hline Married & $111(91)$ & $<0.01$ \\
\hline \multicolumn{3}{|l|}{ Education level } \\
\hline Illiterate & $14(11.5)$ & \\
\hline Primary school & $78(64)$ & 0.02 \\
\hline High school & $27(22.1)$ & \\
\hline University & $5(3.4)$ & \\
\hline \multicolumn{3}{|c|}{ Admission type to Emergency Department } \\
\hline Self-admission & $58(47.5)$ & 0.16 \\
\hline Private vehicles & $37(30.3)$ & \\
\hline By ambulance & $27(22.2)$ & \\
\hline \multicolumn{3}{|c|}{ Retirement status } \\
\hline Retired & $104(85.2)$ & $<0.01$ \\
\hline Not retired & $18(14.8)$ & \\
\hline \multicolumn{3}{|c|}{ Occupational classification } \\
\hline Farmer & $54(44.3)$ & 0.24 \\
\hline Manual worker & $18(14.8)$ & \\
\hline Artisan & $37(30.2)$ & \\
\hline Truck driver & $13(10.7)$ & \\
\hline
\end{tabular}


Only 24 (19.7\%) patients were found to have no comorbidities, and 67 (54.9\%) had two or more comorbidities. Hypertension ( $n=43,35.2 \%$ ) was the most common comorbidity, followed by diabetes mellitus $(n=27,22.1 \%)$, and these were also the most common comorbidities present simultaneously $(n=22$, $18 \%)$. The most common injury mechanism was falls $(n=74,60.7 \%)$, followed by contact with a machine $(n=27,22.1 \%)$. Regarding the injury mechanism, a statistically significant difference was observed in falling injuries $(p=0.015)$ compared with the oth- er injury types. The most commonly injured body part was the extremities ( $n=67,54.9 \% ; p=0.017$ ), followed by the head ( $n=35,28.7 \%)$, thorax $(n=14$, $11.4 \%)$, and abdomen $(n=6,5 \%)$. The most common injury type was a sprain/strain $(n=53,43.4 \%)$, followed by fractures ( $n=27,22.1 \%)$. Sprain/strain type injuries occurred significantly more frequently than other injury types $(p=0.019)$. The comorbidities, injury mechanisms, injured body regions, and injury types are presented in Table 2.

Table 2. Comorbidities, injury mechanisms, injured body regions, and injury types observed in the patients.

\begin{tabular}{lcc}
\hline Comorbidities & $\mathbf{n}(\%)$ & $\mathbf{p}$ \\
\hline None & $24(19.7)$ & 0.28 \\
Hypertension & $43(35.2)$ & \\
Diabetes mellitus & $27(22.1)$ & \\
Respiratory disease & $21(17.2)$ & $<0.01$ \\
Urinary disease & $17(13.9)$ & \\
Musculoskeletal disorder & $15(12.3)$ \\
Gastrointestinal disease & $12(9.8)$ & \\
Malignancy & $7(5.7)$ & \\
\hline Injury mechanism & & \\
\hline Falls & $74(60.7)$ & \\
Contact with a machine & $27(22.1)$ & \\
Chemical exposure & $14(11.5)$ & \\
Kicked by animal & $7(5.7)$ & \\
\hline Injured body part & & \\
\hline Extremity & $67(54.9)$ \\
Head & $35(28.7)$ & \\
Thorax & $14(11.4)$ & \\
Abdomen & $6(5)$ & \\
\hline Type of injury & & \\
\hline Sprain/strain & $58(47.5)$ & \\
Fracture & $27(22.1)$ & \\
Laceration & $27(22.2)$ & \\
Lung injury & $9(7.4)$ & \\
Major head trauma & $7(5.7)$ & \\
\hline & $3(2.5)$ & \\
\hline
\end{tabular}


Although there were no fatal injuries, blunt thorax and abdominal trauma were detected in $16(13.1 \%)$ patients, and major head trauma and traumatic subarachnoid hemorrhage were detected in three (2.5\%) patients. Total 103 (84.4\%) patients were discharged from the emergency department after follow-up and treatment, and 19 (15.6\%) were hospitalized in different services and discharged after receiving follow-up treatment. Most of these patients were transferred to the orthopedics department owing to their extremity traumas, which were statistically more frequent compared to the other departments (p:0.019). The departments and number of patients hospitalized in those are presented in Table 3.

Table 3. The departments and the number of patients hospitalized in them.

\begin{tabular}{lcr}
\hline Department & $\mathbf{n}(\%)$ & $\mathbf{p}$ \\
\hline Orthopedics & $11(57.8)$ & $<0.01$ \\
Neurosurgery & $3(15.7)$ & \\
Plastic surgery & $2(10.5)$ & \\
General surgery & $2(10.5)$ & \\
Thoracic surgery & $1(5.5)$ & \\
\hline
\end{tabular}

In the study period, 758 occupational injury cases between the ages of 18-65 year-old were admitted to the emergency department. Of these, 524 (69.1\%) were male and 234 (30.9\%) were female. The mean age of the patients was $42.8 \pm 14.7$ (mean $\pm \mathrm{SD}$ ). The most common type of injury in this group was buckling-strain injuries ( $\mathrm{n}$ : 256, $33.7 \%)$, and the second was the falling from same or high level (n:115, 15.1\%). These were followed by machine-related injuries (n:82, 10.8\%), motor vehicle accidents ( $n: 55,7.2 \%)$ and other minor injuries. Twelve (1.5\%) of these patients died in the emergency department. Four (33.3\%) of the patients died due to fall from high level, 5 (41.7\%) were due to motor vehicle accidents and $3(25 \%)$ were due to agricultural machinery accidents.

\section{DISCUSSION}

This study aimed to analyze the occupational injuries in individuals aged $>65$ years. In the United States, workers aged $>65$ years old comprise $14 \%$ of the total workforce (8); however, we lack clear data for this rate in our country. Moreover, the United States Bureau of Labor Statistics has stated that the number of workers aged $>55$ years has increased by $49.9 \%$ in the last decade, whereas the number of workers aged $25-54$ years has increased by only $5.5 \%$. These data show that the proportion of elderly workers in the total population will significantly increase in the near future. Likewise, the number of cases of elderly occupational injuries is also predicted to increase.

Male patients accounted for a very large proportion $(85.5 \% \mathrm{n}=108)$ of the included patients. In a study (12) it was stated that; male workers comprised $63 \%$ of the total workers aged $>65$ yearold, and this ratio was stated as $80 \%$ by Turkish Statistical Institution.

We believe that the rate stated by the Turkish Statistical Institution is more accurate because most of the working individuals in our country are men. We think these rates may change if the participation rate of females in the total workforce increases in 
the coming years. Algarni et al. (13) reported that the rate of the elderly workers living alone was $7 \%$; this rate was $9 \%$ in our study. Both rates are quite low when compared with the general population. We believe this rate is low because elderly individuals do not prefer living alone owing to health-related concerns, etc., and the increasing need for support as they age. Berecki et al. (14) reported that elderly workers have higher levels of education. However, in our study, only $5.4 \%$ of the patients were graduates. This low rate may be attributed to most individuals working in agricultural sectors, which has low education requirements. Additionally, in another study (15) it was reported that; elderly workers with higher education levels remained in the labor force for longer durations. We currently lack sufficient data on this subject in our country; however, in our study, the opposite was observed. This differing result may be attributed to the restricted types of jobs available in our country.

People continue to work even after retirement owing to several reasons, the most important being economic difficulties. An interesting finding of the current study was that $85.5 \%$ of the patients continued to actively work despite having retired. The rate of continuing to work after retirement was reportedly $8.6 \%$ in the Netherlands, and $30.8 \%$ in the United States (16). Both studies $(14,15)$ examined the reasons behind individuals continuing to work after retirement and reported the following: 1) they love to work, 2) they think it provides a meaning to their lives, and 3) economic difficulties. However, in our country, financial reasons played the major role in elderly individuals continuing to work.

Algarni et al. (13) reported that $50 \%$ of the individuals aged $>65$ years who were admitted with occupational injuries worked in the transport sector. In our study, we observed that most elderly individuals admitted to the emergency department were farmers (44.3\%). We think the rate of injured farmers was so high because the economy of our region mostly depends on agriculture, and a larger proportion of the population works in this sector. A
Swedish study (17) reported that the mortality rate due to occupational injuries for elderly farmers was $7 \%$. No deaths owing to occupational injuries were reported in our study. We believe that because of the socio-cultural structure of our country, work that heavily lifting should be performed by young workers and not elderly workers. Additionally, 10.7\% of the elderly individuals in our study were truck drivers. Although this proportion is low compared with other studies $(8,13)$, it shows that prohibition of truck driving after 66 years of age is effective in this result. We suspect that this rate would further increase if the age limit is increased, because our region is located at the border, thus providing more opportunities for truck drivers. Yenal et al. (18) reported that $34.2 \%$ of the elderly patients were admitted to the emergency department through an ambulance; this rate was $22.2 \%$ in our study. We think this low rate is related to the low injury severity in these cases. Moreover, trauma-type injuries are perceived as much more urgent by society, and the patients do not always wait for an ambulance.

The most common injury mechanism was falls (60.7\%). Of the 61 patients injured by falling from the same level, 13 fell from a truck, and all the falls occurred either from the top of the truck or when climbing into the truck. Rogers et al. (19) reported that falls were responsible for $33 \%$ of all occupational injuries in the elderly. We think the high rate in our study is related to the comorbidities in the elderly workers; the structure of the working surface was also influential because most individuals worked in the fields. Algarni et al. (13) reported that $62 \%$ of the occupational injuries occurred in the extremities; our study reported a similar rate (54.9\%). We believe this is because extremities can be easily injured during falls and when working with machines. Steege et al. (19) reported that fractures were the most common injury type in the elderly (62.5\%); In contrast, this rate was $22.1 \%$ in our study. We think this difference occurred because the elderly population in our country may be working in less risky jobs in terms of accidents and in jobs with less heavy lifting. The 
most frequent injury type observed in our study was strain/sprain injuries (47.5\%). These injuries were primarily the result of falling from the same level. Increased rates of musculoskeletal disorders also contributed to this high rate.

When the occupational injuries under the age of 65 years and elderly were compared to each other, it was seen that, occupational injuries under the age of 65 were significantly higher $(p=0.024)$. We think that; the much higher ratio of the workers under 65 years of age could be responsible from this result. However, no statistically significant difference was found between these two groups in terms of injury types $(p=0.674)$.

Another important point here is that; no mortal injury was seen in the group over 65 years, while 12 (1.5\%) people lost their lives in the group under 65 years of age. We think that; working in heavier and more risky jobs of the young population compared to the elderly population is responsible fort this result. Pransky et al. (4) reported that occupational injuries were much more severe in older workers than in younger ones. Furthermore, other studies in the literature have reported that the mortality rate due to occupational injuries was higher in older workers than in younger ones. We think that occupational injuries in the elderly are mostly related to truck accidents and that the high mortality rate due to this type of trauma contributes to the overall high mortality rate.

\section{REFERENCES}

1. Breslin FC, Smith P. Age-related differences in work injuries; a multivariate, population-based study. Am J Ind Med 2005;48(1):50-6. (PMID:15940721).

2. Breslin C, Koehoorn M, Smith P, Manno M. Age related differences in work injuries and permanent impairment: a comparison of workers' compensation claims among adolescents, young adults, and adults. Occup Environ Med. 2003;60:1-6. [Internet] Available from: http://www.occenvmed.com/cgi/ content/full/60/9/e10 (PMID:12937206). Accessed: 22.08.2018.
Our study has some limitations. This study was conducted at only one center. Additionally, there could have been some bias in patient selection because we only included patients who declared their occupational injury at their first application. However, some elderly patients could have had declared their injuries as domestic accidents instead of occupational accidents to refrain from legal procedures. Finally, the rates of informal working in the elderly population could not be clearly determined.

In conclusion, the life expectancy is increasing in our country as well as worldwide. Additionally, the proportion of the elderly population in the total workforce will increase in the coming years for many reasons. Further, the risk of occupational injuries is increasing in concert with the decrease in cognitive and physical abilities in the elderly population. Thus, occupational injuries in the elderly should be more carefully evaluated in the emergency department, and their comorbidities must be considered when providing treatment. We believe this study will be a guide for future studies evaluating occupational accidents in the elderly in our country.

\section{Conflicts of interest}

None.

3. Leigh JP, Du J, McCurdy SA. An estimate of the U.S. government's undercount of nonfatal occupational injuries and illnesses in agriculture. Ann Epidemiol 2014;24(4):254-9. (PMID:24507952).

4. Pransky GS, Benjamin KL, Savageau JA, Currivan $D$, Fletcher K. Outcomes in work-related injuries: a com- parison of older and younger workers. Am J Ind Med 2005;47:104-12. (PMID:15662646).

5. Wiktorowicz J. Extending Working Life: Which Competencies are Crucial in Near-Retirement Age? J Adult Dev. 2018; 25:48-60. (PMID:29527111). 
6. Turkish Statistical Institute. News Bulletin. Elderly with Statistics 2017. 2018;27595. [Internet] Available from: http://www.tuik.gov.tr/PreHaberBultenleri. do?id=27595. Accessed: 15.03.2018. (in Turkish).

7. Hwang K, Huan F, Hwang JP. Comparison of Facial Trauma in Late Middle Age (55-64 Years) and Old Age (Older Than 65 Years). J Craniofac Surg 2013;24:90913. (PMID:23714909).

8. Classen S, Wang Y, Crizzle AM, Winter SM, Lanford DN. Gender differences among older drivers in a comprehensive driving evaluation. Accident Analysis and Prevention 2013;61:146-52. (PMID:23141026).

9. Kenny GP, Yardley JE, Martineau L, Jay O. Physical work capacity in older adults: implications for the aging worker. Am J Ind Med 2008;51:610-25. (PMID:18543279).

10. Melikoğlu MA, Kul A. Fall risks and related factors in knee osteoarthritis. Turkish Journal of Geriatrics 2018;21(1): 49-55.

11. Chau N, Bhattacherjee A, Kunar BM, Group L. Relationship between job, lifestyle, age and occupational injuries. Occup Med 2009;59(2):114-9. (PMID:19233831).

12. McNamara TK, Brown M, Aumann K, Pitt-Catsouphes M, Galinsky E, Bond JT. Working in retirement: a brief report. J Appl Gerontol 2013;32(1):120-32. (PMID:25473928).

13. Algarni FS, Gross DP, Senthilselvan A, Battié MC. Ageing workers with workrelated musculoskeletal injuries. Occup Med 2015;65(3):229-7. (PMID:25759069).
14. Berecki GJ, Clay FJ, Collie A, McClure RJ. The impact of aging on work disability and return to work: insights from workers' compensation claim records. J Occup Environ Med 2012;54:318-27. (PMID:22371057).

15. Beach B. Ageing populations and changing worlds of work. Maturitas 2014;78(4):241-2. (PMID:24931302).

16. De Wind $A$, van der Pas $S$, Blatter BM, van der Beek AJ. A life course persperctive on working beyond retirement-results from a longitudinal study in the Netherlands. BMC Public Health 2016;16(10):499. (PMID:27287303).

17. Nilsson K, Pinzke S. Occupational accidents among elderly farmers in Sweden. Work 2012;4:5324-26. (PMID:22317544).

18. Yenal S, Keser G, Mandıracıoğlu A, Yalçın MA, Bayram B, Akçiçek F. The Determination of the Status of Emergency Department Use by Elderly Patients and of the Indicators For Ambulance Use. Turkish Journal of Geriatrics 2018;21(2):109-17.

19. Steege AL, Baron SL, Marsh SM, Menéndez CC, Myers JR. Examining occupational health and safety disparities using national data: a cause for continuing concern. Am J Ind Med 2014;57(5): 527-38. (PMID:2446156). 